\title{
Risk of phosphorus losses in surface runoff from agricultural land in the Baltic Commune of Puck in the light of assessment performed on the basis of DPS indicator
}

\author{
Stefan Pietrzak ${ }^{\text {Corresp., }{ }^{\text {, }} \text {,Grażyna Pazikowska-Sapota }}{ }^{2}$, Grażyna Dembska ${ }^{2}$, Lidia Dzierzbicka-Głowacka ${ }^{3}$, Dominika \\ Juszkowska $^{1}$, Zuzanna Majewska ${ }^{1}$, Marek Urbaniak ${ }^{1}$, Dominika Ostrowska ${ }^{2}$, Agnieszka Cichowska ${ }^{2}$, Katarzyna \\ Galer-Tatarowicz $^{2}$ \\ ${ }^{1}$ Department of Water Quality, Institute of Technology and Life Sciences in Falenty, Raszyn, Poland \\ 2 Department of Environmental Protection, Maritime Institute, Gdańsk, Poland \\ 3 Physical Oceanography Department, Eco-hydrodynamics Laboratory, Institute of Oceanology of the Polish Academy of Sciences, Sopot, Poland \\ Corresponding Author: Stefan Pietrzak \\ Email address: s.pietrzak@itp.edu.pl
}

Background. In order to counteract the eutrophication of waterways and reservoirs, a basic risk assessment of phosphorus (P) losses in the surface runoff from agricultural land should be included in water management plans. A new method has been developed to assess the risk of $\mathrm{P}$ losses by estimating the degree of $\mathrm{P}$ saturation (DPS) based on the $\mathrm{P}$ concentration of the water extract (water-soluble $\mathrm{P}$ WSP).

Methods. The risk of P losses in surface runoff from agricultural land in the Puck Commune on the Baltic Sea Coast was assessed with the DPS method. The results were compared to an agronomic interpretation of the soil test P concentration (STP). Research was conducted on mineral and organic soils from 50 and 11 separate agricultural plots with a total area of 133.82 and 37.23 ha, respectively. $P$ was extracted from the collected samples using distilled water on all soil samples, acid ammonium lactate on mineral soils, and an extract of $0.5 \mathrm{~mol} \mathrm{HCl} \cdot \mathrm{dm}^{-3}$ on organic soils. The organic matter content and $\mathrm{pH}$ values were also determined. The results of the $\mathrm{P}$ content in the water extracted from the soils were converted into DPS values, which were then classified by appropriate limit intervals.

Results \& Discussion. There was a high risk of P losses from the soil via surface runoff in $96.7 \%$ of the agricultural parcels tested (96\% of plots with mineral soils and $100 \%$ of plots with organic soils).

Simultaneously, a large deficiency of plant-available P was found in soils from $62 \%$ of agricultural plots. These data indicate that the assessment of $\mathrm{P}$ concentration in soils made on the basis of an environmental soil P test conflicts with the assessment made based on STP and create a cognitive dissonance. The risk level of P losses through surface runoff from the analyzed plots as determined by the DPS indicator is uncertain. This uncertainty is increased as the DPS index is not correlated with other significant factors in P runoff losses, such as the type of crop and area inclination. 
1 Risk of phosphorus losses in surface runoff from

2 agricultural land in the Baltic Commune of Puck in the light

\section{3 of assessment performed on the basis of DPS indicator}

4

5 Stefan Pietrzak ${ }^{1}$, Grażyna Pazikowska-Sapota ${ }^{2}$, Grażyna Dembska ${ }^{2}$, Lidia Dzierzbicka-

6 Głowacka $^{3}$, Dominika Juszkowska ${ }^{1}$, Zuzanna Majewska ${ }^{1}$, Marek Urbaniak ${ }^{1}$, Dominika

7 Ostrowska ${ }^{2}$, Agnieszka Cichowska ${ }^{2}$, Katarzyna Galer-Tatarowicz ${ }^{2}$

8

$9{ }^{1}$ Department of Water Quality, Institute of Technology and Life Sciences in Falenty, Raszyn,

10 Poland

112 Department of Environmental Protection, Maritime Institute, Gdańsk, Poland

$12{ }^{3}$ Physical Oceanography Department, Eco-hydrodynamics Laboratory, Institute of Oceanology

13 of the Polish Academy of Sciences, Sopot, Poland

15 Corresponding Author:

16 Stefan Pietrzak

17 Hrabska 3, 05-090 Raszyn, Poland 


\section{Abstract}

21 Background. In order to counteract the eutrophication of waterways and reservoirs, a basic risk assessment of phosphorus (P) losses in the surface runoff from agricultural land should be included in water management plans. A new method has been developed to assess the risk of $\mathrm{P}$ losses by estimating the degree of $\mathrm{P}$ saturation (DPS) based on the $\mathrm{P}$ concentration of the water extract (water-soluble P - WSP).

Methods. The risk of $\mathrm{P}$ losses in surface runoff from agricultural land in the Puck Commune on the Baltic Sea Coast was assessed with the DPS method. The results were compared to an agronomic interpretation of the soil test P concentration (STP). Research was conducted on mineral and organic soils from 50 and 11 separate agricultural plots with a total area of 133.82 and 37.23 ha, respectively. P was extracted from the collected samples using distilled water on

31 all soil samples, acid ammonium lactate on mineral soils, and an extract of $0.5 \mathrm{~mol} \mathrm{HCl} \cdot \mathrm{dm}^{-3}$ on organic soils. The organic matter content and $\mathrm{pH}$ values were also determined. The results of the

P content in the water extracted from the soils were converted into DPS values, which were then

34 classified by appropriate limit intervals.

35 Results \& Discussion. There was a high risk of P losses from the soil via surface runoff in $96.7 \%$ of the agricultural parcels tested $(96 \%$ of plots with mineral soils and $100 \%$ of plots with 
37 organic soils). Simultaneously, a large deficiency of plant-available $\mathrm{P}$ was found in soils from

$3862 \%$ of agricultural plots. These data indicate that the assessment of $\mathrm{P}$ concentration in soils

39 made on the basis of an environmental soil P test conflicts with the assessment made based on

40 STP and create a cognitive dissonance. The risk level of P losses through surface runoff from the

41 analyzed plots as determined by the DPS indicator is uncertain. This uncertainty is increased as

42 the DPS index is not correlated with other significant factors in P runoff losses, such as the type

43 of crop and area inclination.

\section{Introduction}

46 The Baltic Sea is a basin affected by strong eutrophication (Andersen et al., 2011; HELCOM,

$472018 b$ ) resulting in many adverse changes in the marine flora and fauna (Ojaveer et al., 2010),

48 which can lead to large social and economic losses (Ahtiainen et al., 2014). One of the main

49 reasons for the eutrophication of the Baltic Sea waters is the excessive river inflow of

50 phosphorus $(\mathrm{P})$. The inflow from the entire Baltic basin is estimated at 29.3 tons per year, of

51 which $35.7 \%$ comes from dispersed sources, mainly agriculture (HELCOM, 2018a). About 12.7

52 tons of $\mathrm{P}$ is estimated to come from Poland to the Baltic Sea by river waters (HELCOM, 2018a)

53 and $21 \%$ to $33 \%$ of this comes from the agricultural sector, depending on the method of

54 assessment $(N W M B, 2016 a)$. In order to counteract the eutrophication of the Baltic Sea, various 
56 of the Baltic Sea. Important measures were prepared at the Conference of Ministers for the

57 Environment of the HELCOM countries in Copenhagen on 3 October 2013, specifying the

58 expected reduction of the total P loads discharged into the Baltic Sea by the HELCOM member

59 states (HELCOM, 2013). Accordingly, Poland is expected to reduce the $\mathrm{P}$ inflow to the Baltic

60 Sea by $51 \%$ of that expelled during the reference period from 1997-2003 (NWMB, 2016a).

61 Poland approved this level of reduction as a rough estimate, noting that a final figure would be

62 accepted after relevant analyses were conducted. In light of this measure, Polish agriculture is expected to face major challenges in meeting this requirement, including the impact it will have

64 on inland surface waters. According to Polish monitoring data, eutrophication parameters

65 (nutrient and chlorophyll-a concentration, water transparency) between 2012 and 2015 were

66 exceeded by $42 \%$ for sites located on flowing waters (rivers) and by $66 \%$ for stands on stagnant

67 waters (lakes/water reservoirs) (NWMB, 2016b). Effective solutions to reduce P loss from agricultural sources to waters are needed in light of the Conference's provisions and certain economic factors. Tools and procedures for controlling agricultural lands in case of $\mathrm{P}$ loss in

70 surface runoff should minimize the threat posed by excess $\mathrm{P}$ in aquatic ecosystems. The threat to rivers and reservoirs by P loss from agricultural soils has been of interest to researchers for years.

72 This problem is most commonly considered in terms of interactions between the content of plant-

73 available $\mathrm{P}$ in soil (determined by various methods, for example Mehlich 3, Olsen, Egner-

74 Riehm), and P concentration in runoff water; it has been proven that an increase in the $\mathrm{P}$ content 
75 in soil will correspond to an increased amount of $\mathrm{P}$ in surface runoff (Pole et al., 1996; Torbert

76 et al., 2002; Sharpley \& Kleinman, 2003; Pietrzak, Wesołowski \& Brysiewicz, 2017). However,

77 the system for cultivating plants and the type of soil also have an impact (Gaj, 2008 after:

78 Sharpley et al., 1981). The existing agrochemical tests for evaluating P levels are not equally

79 useful for testing in all soil types, limiting their use.

80 Another applied approach to assessing P loss from agricultural soils via rainwater and the risk of

81 surface water eutrophication is based on the determination of the degree of P saturation (DPS)

82 (Alleoni, Fernandes \& de Campos, 2014). The DPS in its classical formula is expressed in a

83 percentage relation of the $\mathrm{P}$ content in the soil extract to the $\mathrm{P}$ absorption capacity of soil,

84 wherein various approaches are used for the determination of the components in this formula

85 (Nair et al., 2004; Casson et al., 2006). The procedure for determining the DPS index according

86 to this formula is unique for different types of soil, which can create specific methodological

87 problems and limit the possibilities of its wider use (Sapek, 2007). Pöthig et al. (2010) recently

88 developed a different method for determining this index, in which the DPS indicator only

89 depends on the P content in soil as determined by the use of distilled water - WSP (water-soluble

90 P). This method is attractive for its simplicity and broad application with different soil types. In

91 the MONERIS model (Modelling Nutrient Emissions into River Systems), developed for

92 quantifying the amount of nutrient emissions from point and diffuse sources in river catchments 
93 (Venohr et al., 2011 after: Behrendt et al., 2000), the method proposed by Pöthig et al. (2010) is

94 used to determine the $\mathrm{P}$ concentration in surface runoff.

95 This work sought to estimate the risk of P loss in surface runoff from agricultural soils in the

96 Puck Commune using the DPS indicator determined on the basis of WSP, and to identify the

97 practical utility of the DPS index.

99 Material \& Methods

100 Research was conducted on the western shore of Puck Bay on the Baltic Sea in the Puck

101 Commune, which is located in the north-eastern region of the Pomeranian Voivodeship, Poland.

102 The Puck Commune is dominated by agricultural land (57.3\% of the total area of the commune),

103 the vast majority of which is characterized by high yield potential. The area is largely undulating,

104 with land falls up to approximately $9 \%\left(5.14^{\circ}\right)$. Such landform features increase the risk of P loss

105 in surface runoff.

106 This study is a part of the project "Modelling of the impact of the agricultural holdings and land

107 use structure on the quality of inland and coastal waters of Baltic Sea set up on the examples of

108 the Municipality of Puck region - Integrated info-prediction Web Service WaterPUCK”

109 (Dzierzbicka-Głowacka et al., 2019).

110 In the spring of 2018, soil samples from 61 agricultural plots on 22 farms were taken (field work

111 was conducted with the landowners'/farmers' permission) for chemical analysis based on the 
112 guidelines included in the PN-R-04031:1997 standard. An aggregate sample was created by

113 combining and thoroughly mixing a set of primary (individual) samples of up to 20 items.

114 Laboratory analysis of the aggregate samples determined the organic matter content in the layer

115 of $0-5 \mathrm{~cm}, \mathrm{pH}$ in the layer $0-30 \mathrm{~cm}$, the concentration of plant-available $\mathrm{P}$ in layers $0-5 \mathrm{~cm}$ and $0-$

$11630 \mathrm{~cm}$, and the content of WSP in the layer of 0-5 cm (WSP_w1). In this regard:

117 (1) fraction content below $0.02 \mathrm{~mm}$ was determined by the sedimentation (pipette) method

118 according to PN-EN ISO 17892-4:2016 standard;

119 (2) organic matter content was determined as a loss on ignition at $550^{\circ} \mathrm{C}$ by the weight

120 method according to the PN-EN 12879:2004 standard;

121 (3) $\mathrm{pH}$ measurement of soil was conducted in $1 \mathrm{~N}$ suspension of $\mathrm{KCl}$ solution by

122 potentiometric method according to PN-ISO 10390:1997 standard $\left(\mathrm{pH}_{\mathrm{KCl}}\right)$;

123 (4) the concentration of available P forms (in agronomic soil P test - STP) in mineral soils

124 was determined by acid ammonium lactate $(\mathrm{pH} \sim 3.55)$ according to the PN-R-04023:1996

125 standard $\left(\mathrm{P}_{\mathrm{AL}}\right)$ and by the extract of $0.5 \mathrm{~mol} \mathrm{HCl} \cdot \mathrm{dm}^{-3}$ according to PN-R-04024:1997

126 standard $\left(\mathrm{P}_{\mathrm{HCl}}\right)$ in organic soils; the content of WSP (in environmental soil $\mathrm{P}$ test) in $\mathrm{mg} \mathrm{P}_{\mathrm{kg}}{ }^{-1}$

127 of soil, was determined by Inductively Coupled Plasma Optical Emission Spectroscopy ICP-

128 OES after drying soil samples in the air and sieving them through a $<2 \mathrm{~mm}$ sieve, preparing a

129 suspension in the ratio of $1 \mathrm{~g}$ of soil in $50 \mathrm{ml}$ of distilled water, agitating for 2 hours, and

130 filtering through a $0.45 \mu \mathrm{m}$ filter. 
131 Soil samples analysis was ordered and evaluated according to the following criteria:

132 (1) Based on the soil organic matter (SOM) content, the soils were divided into mineral and organic soils. With the SOM content of more than 10\% (threshold value between mineral and organic soils) organic soil was classified as organic (Szymanowski, 1995; PN-R04024:1997).

(2) The assessment of soil acidification was conducted according to the accepted standards.

(3) An assessment of P content in soil was conducted with respect to threshold values given the following standards: PN-PN-R-04023:1996 and PN-R-04024:1997 for the following abundance classes: very low, low, medium, high, and very high (Table 1). The basis for the assessment was the percentage share of the soil samples tested in individual concentration classes.

(4) Based on the results of the P content determination in soil using water extract, DPS, in \%, indices were calculated using the equation (Pöthig et al., 2010):

$\operatorname{DPS}(\%)=\left\{1 /\left[1+\left(1.25 \cdot W S P^{-0.75}\right)\right]\right\} \cdot 100$

148 where: WSP - is the content of water soluble $\mathrm{P}, \mathrm{mg} \mathrm{P} \cdot \mathrm{kg}^{-1}$ of soil. 
149 The risk of P loss by surface runoff was assessed using the limit intervals specified by Pöthig et

150 al. (2010) and the established P saturation indexes (Fig. 1). There is a high risk of P loss from the

151 soil by surface runoff if the DPS value exceeds $80 \%$, DPS values lower than $70 \%$ were

152 considered safe, and values between 70 and $80 \%$ were considered to be tolerable.

153 The laboratory results were evaluated statistically to determine the basic parameters of the

154 descriptive statistics and any correlations between the analyzed soil indices. The statistics of the

155 results were prepared with Statistica 6 software (StatSoft).

156 Indoor work and interviews with farmers from 22 farms were conducted to determine the

157 consumption of $\mathrm{P}$ fertilizers, the area and type of development of the agricultural plots, the

158 categories, types, soil types and subtypes, and the inclination of the slopes in the research areas.

159 Specially prepared questionnaires were completed by the farmers based on their own

160 observations of the terrain, a soil agricultural map of the Puck Commune in a vector format

161 (IUNG-PIB), and maps of selected agricultural plots acquired from Google Earth Pro.

162

163 Results

164 Soils were taken from 61 separate agricultural plots with a total area of 171.05 ha. 50 plots with a

165 total area of 133.82 ha were agricultural lands (AL) with mineral-derived soils and an organic

166 matter content of 2.53-7.01\%; 11 plots were AL with organic soils characterized by organic

167 matter content of $25.60-68.17 \%$ with a total area of 37.23 ha. The following types and subtypes

Peer) reviewing PDF | (2019:05:37685:3:0:NEW 6 Dec 2019) 
168 of soils occurred in the research area in the given proportions: brown soils, $61.9 \%$; brown soils,

169 lessive soils, podzolic soils, and rusty soils made from gravel and sands, 10.2\%; lessive soils,

$1703.7 \%$; black soils, 2.4\%; and peat and muck-peat soils, 21.8\%. Among mineral soils, medium

171 soils with a $21-35 \%$ content of particles with diameter less than $0.02 \mathrm{~mm}$ were the majority,

172 covering $49.7 \%$ of their area, followed by very light (up to 10\% content), and light soils (11-20\%

173 content), whose share in the mineral soil area was 39.1 and $11.2 \%$, respectively. Grains were the

174 predominant crop on most of the plots with mineral soils, while most of the plots with organic

175 soils were covered with permanent grassland. These plots was largely undulating (Fig. 2), with

176 landfalls of up to $9 \%\left(5.14^{\circ}\right)$, increasing the danger of $\mathrm{P}$ loss from surface runoff.

177 In 2017, the average consumption of $\mathrm{P}$ fertilizers on the farms where the agricultural plots were

178 located was $11.1 \mathrm{~kg} \mathrm{P} \cdot \mathrm{ha}^{-1}$ of AL with a range of $0-24.9 \mathrm{~kg} \mathrm{P} \cdot \mathrm{ha}^{-1} \mathrm{AL}$ on the individual farms.

179 This type of fertilizer was used in over 54\% of agricultural holdings in doses of 5-10 and 10-15

$180 \mathrm{~kg} \mathrm{P} \cdot \mathrm{ha}^{-1}$ AL (Table 2).

181 The analyzed soils in the $0-30 \mathrm{~cm}$ layer were characterized by a $\mathrm{pH}_{\mathrm{KCl}}$ within $4.2-7.2$ (average

182 5.4) and 4.9-6.3 (average 5.5) in the case of mineral and organic soils, respectively; this soil

183 depth is treated as a diagnostic layer in the analysis of the agrochemical properties of soils to

184 determine proper fertilizer use. The available $\mathrm{P}$, concentrated in the $0-30 \mathrm{~cm}$ layer of the

185 analyzed soils, reached values from 3.6 to $66.5 \mathrm{mg} \mathrm{P} \mathrm{AL}_{\mathrm{AL}} \cdot \mathrm{kg}^{-1}$ (average $33.3 \mathrm{mg} \mathrm{P}_{\mathrm{AL}} \cdot \mathrm{kg}^{-1}$ ) in

186 mineral soils, and from 171.0 to $707.0 \mathrm{mg} \mathrm{P} \mathrm{PCl}_{\mathrm{HCl}} \cdot \mathrm{kg}^{-1}$ (average $340.6 \mathrm{P}_{\mathrm{HCl}} \cdot \mathrm{kg}^{-1}$ ) in organic soils. 
187 The highest amounts of $\mathrm{P}$ were found in light soils (average $42.2 \mathrm{mg} \mathrm{P} \mathrm{AL} \cdot \mathrm{kg}^{-1}$ ) while in very light

188 and medium soils the $\mathrm{P}$ content was similar (25.6 and $\left.25.8 \mathrm{mg} \mathrm{P}_{\mathrm{AL}} \cdot \mathrm{kg}^{-1}\right)$. In the $0-5 \mathrm{~cm}$ soil layer

189 the $\mathrm{P}$ concentration ranged from 3.6 to $68.8 \mathrm{mg} \mathrm{P}_{\mathrm{AL}} \cdot \mathrm{kg}^{-1}$ (average $35.4 \mathrm{mg} \mathrm{P}_{\mathrm{AL}} \cdot \mathrm{kg}^{-1}$ ) in mineral

190 soils and from 136.0 to $526.0 \mathrm{mg} \mathrm{P} \mathrm{HCl} \cdot \mathrm{kg}^{-1}$ (average $284.6 \mathrm{P}_{\mathrm{HCl}} \cdot \mathrm{kg}^{-1}$ ) in organic soils; this soil

191 depth is treated as a standard in environmental research for establishing relationships between

192 the quantitative state of P in soil and surface runoff (Sharpley et al., 1985; Schindler, German \&

193 Gelderman, 2002; Schierer, Davis \& Zumbrunnen, 2006; Hansen et al., 2012). In this layer, the

194 P concentration in mineral soils was $6.5 \%$ higher, on average, than in the $0-30 \mathrm{~cm}$ layer.

195 However, the P concentration was 16.6\% lower in organic soils. In turn, the WSP_w1 content in

196 the tested mineral and organic soils as determined by water extract was in the range of 2.2-58.5

$197 \mathrm{mg} \mathrm{WSP} \cdot \mathrm{kg}^{-1}$ (average $24.6 \mathrm{mg} \mathrm{WSP} \cdot \mathrm{kg}^{-1}$ ) and $13.7-79.5 \mathrm{mg} \mathrm{WSP} \cdot \mathrm{kg}^{-1}$ (average $40.3 \mathrm{mg}$

$\left.198 \mathrm{WSP} \cdot \mathrm{kg}^{-1}\right)$, respectively. At this level of mineral soils there was $39.0 \%$ less $\mathrm{P}$, on average, than in

199 organic soil. In mineral soils the content of WSP_w1 was variable depending on their type; on

200 average it was $20.0,32.8$, and $17.0 \mathrm{mg} \mathrm{WSP} \cdot \mathrm{kg}^{-1}$ in very light, light, and medium soils,

201 respectively.

202

203 Discussion

204 Soil pH and abundance in plant-available $\mathbf{P}$ 
$205 \mathrm{pH}$ is one of the most important factors determining the physical, chemical, and biological

206 properties of soil. It affects the availability of $\mathrm{P}$ accumulated in soil for plants and the $\mathrm{P}$ loss to

207 the environment (von Tucher, Hörndl \& Schmidhalter, 2018). The soil acidity test revealed that

$20862.3 \%$ of plots were characterized by a very acidic or acidic reaction; $31.1 \%$ of plots were

209 slightly acidic and 6.6\% were neutral, whereby the share of mineral and organic soils in

210 individual reaction classes was varied (Fig. 3). These conditions are common in the Puck

211 Commune where $13 \%$ and $54 \%$ of the soils are considered very acidic and acidic, respectively

212 (Puck Commune Office, 2016). In the Pomeranian Voivodeship and Poland these fractions

213 reduce to $10 \%$ and $31 \%$, and $12 \%$ and $25 \%$, respectively (GUS, 2018). The range of optimum $\mathrm{pH}$

214 values are assumed to be 5.6 to 7.0 for mineral soils (in which the majority of cultivated species

215 of plants in Poland grow) (Kocoń, 2014) and 4.5 to 5.5 for organic soils (Barszczewski,

216 Jankowska-Huflejt \& Mendra, 2015 after: Moraczewski, 1996). These values represented the

217 soils covering $34.4 \%$ of plots, including $30 \%$ of plots with mineral soils and $54.5 \%$ of plots with

218 organic soils. These data indicate that more than $1 / 3$ of the soil $\mathrm{pH}$ from the research areas were

219 very unfavorable from an agronomic and environmental point of view.

220 Results of STP revealed that in about $62.3 \%$ of plots the P content was very low to low, while

$22132.8 \%$ had a medium content of P (Fig. 4). In 4.9\% of all plots, soil fertility had high or very

222 high levels of P. Organic soils were not as abundant in the very low and low classes of P content

223 but were much higher in the medium and very high classes of $\mathrm{P}$ content, compared with mineral 
224 soils. Soils with high P deficiencies (very low and low P content) should be intensively fertilized

225 with P to protect high plant yields and increase the soil fertility (Jadczyszyn, Kowalczyk \&

226 Lipiński, 2010). During the research period relatively large P fertilizer doses were used on the

227 farms studied, with an average of more than $11 \mathrm{~kg} \mathrm{P} \cdot \mathrm{ha}^{-1} \mathrm{AL}$. These doses are comparable to the

228 level of P fertilization used on a Poland-wide basis of $10.3 \mathrm{~kg}$ P·ha ${ }^{-1} \mathrm{AL}$ (GUS 2019). However,

229 these doses exceed the average amount of P fertilizers used in EU countries with well-developed

230 agriculture, such as in Germany where the dose is $7.5 \mathrm{~kg} \mathrm{P} \cdot \mathrm{ha}^{-1} \mathrm{AL}$, or in Denmark and Sweden

231 where the doses are $5.5 \mathrm{~kg} \mathrm{P} \cdot \mathrm{ha}^{-1} \mathrm{AL}$ and $3.1 \mathrm{~kg} \mathrm{P} \cdot \mathrm{ha}^{-1} \mathrm{AL}$, respectively (GUS 2018).

232 The distribution of soil $\mathrm{pH}$ and the available $\mathrm{P}$ forms concentration had a rather irregular spatial

233 arrangement (Fig. 5). Very low or low $\mathrm{P}$ content in the $0-30 \mathrm{~cm}$ layer of soil with very acidic and

234 acidic reaction was noted.

235

236 Assessment of DPS indicator

237 The DPS index was calculated based on the WSP in the analyzed soils and was in the range of

$23859.1-95.5 \%$ (average 88.4\%) (Table 3). It should be noted that organic soils were characterized

239 by higher DPS values than mineral soils.

240 DPS values were set at 80\% and higher for soils from 59 plots, including 48 mineral soils and 11

241 organic soils (Table 4). There was a high risk of $\mathrm{P}$ losses to water when the approach to

242 determining this risk suggested by Pöthig et al. (2010) was followed, however the accuracy of 
243 this method is in question. In order to verify the method, additional studies determining the

244 relationship between WSP/DPS and P concentration in surface runoff need to be conducted.

245 Studies of this nature conducted in northwestern Poland (53 $\left.16^{\prime} 2.46^{\prime \prime} \mathrm{N}, 14^{\circ} 46^{\prime} 9.42^{\prime \prime} \mathrm{E}\right)$ showed

246 that the soluble phosphate concentration $\left(\mathrm{P}-\mathrm{PO}_{4}\right)$ in surface runoff from mineral soils with a $\mathrm{P}$

247 content of $10.3-86.1 \mathrm{mg} \mathrm{WSP} \cdot \mathrm{kg}^{-1}$ (average $23.2 \mathrm{mg} \mathrm{WSP} \cdot \mathrm{kg}^{-1}$ ) ranged from 0.34 to 17.89

$248 \mathrm{mg} \cdot \mathrm{dm}^{-3}$ (average $\left.3.11 \mathrm{mg} \cdot \mathrm{dm}^{-3}\right)$ (Pietrzak, Majewska \& Wesołowski, 2016). From mineral soils

249 with an average WSP content of $24.6 \mathrm{mg} \cdot \mathrm{kg}^{-1} \mathrm{P}_{-} \mathrm{PO}_{4}$ in surface runoff were obtained under

250 specific conditions.

251 The high DPS values observed over the majority of the research area suggest that P fertilization

252 should be limited for environmental reasons. This conclusion is in contrast to the conclusion

253 made based on the results of the STP; more research is needed to reconcile the observed conflict

254 between the results of P soil tests obtained by agronomic and environmental testing methods.

255 Soil sorption properties researched in close proximity to the current research area as part of the

256 arable soils chemism monitoring in Poland can indirectly assist in understanding these

257 antagonistic assessments (Table 5). The results of this research indicated that the soil was

258 characterized by its content of exchangeable aluminum (ExAl), a relatively low cation exchange

259 capacity (CEC), and low soil buffering capacity. Typical CEC and ExAl values for similar soils

260 in Poland are from 7.18 to 10.38 and from 0.33 to $0.41 \mathrm{cmol}(+) \cdot \mathrm{kg}^{-1}$, respectively $($ Fotyma \&

261 Mercik, 1995). A small ExAl content in the monitored soil could have been caused by the 
262 applied $\mathrm{P}$ fertilization which resulted in the reduction of free $\mathrm{Al}^{3+}$ ions (Filipek, 1989; Brzeziński

$263 \&$ Barszczak, 2009) due to the precipitation of insoluble aluminum phosphates. In the soils

264 obtained from the majority of research plots, the $\mathrm{Al}^{3+}$ content level may have been low, which

265 may explain large deficiencies in available P as established by STP. More reliable assessments of

266 P content in the tested soils were obtained by the agronomic test method compared to

267 environmental test methods.

268

269 Statistical analysis of research results

270 There were numerous interactions between the analyzed soil indices. These interactions occurred

271 between indices describing mineral soils in which each parameter analyzed was correlated with

272 all others (according to the peer-to-peer mechanism) (Table 6). These revealed positive,

273 moderate-to-strong dependencies.

274 There was a relatively low correlation between the $\mathrm{pH}_{\mathrm{KCl}}$ value of the soil and the $\mathrm{P}_{\mathrm{AL}}$ content

275 determined in the layer up to 5 and $30 \mathrm{~cm}$. However, this correlation indicates that by reducing

276 the acidity of soils, the available $\mathrm{P}$ would increase. The $\mathrm{pH}_{\mathrm{KCl}}$ of soil is has a major and direct

277 impact on the P availability. In acidic soils, a large part of this component is immobilized by

278 manganese (Mn), iron (Fe) or aluminum (Al) compounds. The use of liming on such soils

279 increases the amount $\mathrm{P}$ available for plant uptake. 
280 The $\mathrm{P}_{\mathrm{AL} \_} \mathrm{w} 2$ and $\mathrm{P}_{\mathrm{AL}}{ }_{\mathrm{W}} \mathrm{w} 1$ contents were most strongly correlated with each other, which

281 indicated that $\mathrm{P}$ was uniformly accumulated in the topsoil $(0-30 \mathrm{~cm})$. Therefore, the data

282 regarding the $\mathrm{P}$ state may prove equally useful to quantify $\mathrm{P}$ loss in surface runoff from

283 agricultural land at each of the mentioned levels. The possibility of using soil samples from

284 levels deeper than $5 \mathrm{~cm}$ to assess the risk of $\mathrm{P}$ losses in surface runoff was also suggested by

285 Fischer et al. (2018) in studies conducted in Brazil that used P determinations in the $0-20 \mathrm{~cm}$

286 layer using the Mehlich-1P test (M1P) to calculate the DPS indicator values on the basis of the

287 M1P-WSP correlation as determined by a set of soil samples.

288 There were fairly strong correlations between WSP_w1 and $\mathrm{P}_{\mathrm{AL}}$ content. Similarly strong

289 relationships were found between WSP and $\mathrm{P}_{\mathrm{AL}}$ content in Brazilian and German soils defined

290 by M1P and CAL (calcium-acetate-lactate) methods based on the P-extraction by a mixture of

291 calcium lactate and calcium acetate (Fischer, 2018). In case of such correlations, it is possible to

292 convert the results obtained with one method to another with great accuracy. The existence of a

293 relatively strong relationship between $\mathrm{WSP}_{-} \mathrm{w} 1$ and $\mathrm{P}_{\mathrm{AL} \_} \mathrm{w} 2$ and $\mathrm{P}_{\mathrm{AL} \_} \mathrm{w} 1$, continued as the latter

294 two indices also remained in a strong relationship with the DPS indicator as a result that DPS is a

295 function of WSP_w1 $(\mathrm{R}=1)$.

296 While all the analyzed indices in mineral soils were correlated, in organic soils only $\mathrm{P}_{\mathrm{HCl}} \mathrm{w} 1$ and

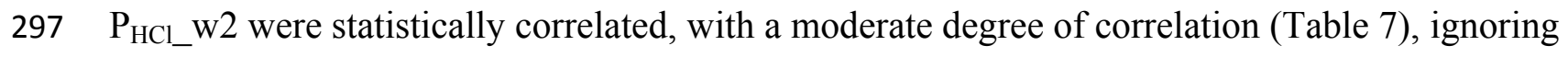

298 the natural relationship between DPS and WSP_w1. 
299 The correlation between the $\mathrm{P}_{\mathrm{HCl}}$ content in organic soil at depths of 0-5 and 0-30 cm was weaker

300 than in mineral soils, which may be due to the fact that they were not usually mixed when used

301 and therefore did not favor the homogenization of their top layer composition, including P

302 content. The lack of correlation between $\mathrm{WSP}_{-} \mathrm{w} 1, \mathrm{P}_{\mathrm{HCl}} \mathrm{w} 2$, and $\mathrm{P}_{\mathrm{HCl}} \mathrm{w} 1$ indicates that $\mathrm{P}$

303 transfers from soil to water and to $0.5 \mathrm{~mol} \mathrm{HCl}$ extracts differently and in disproportionate

304 amounts due to their different extraction possibilities.

Discrepancy between DPS indicator and STP' results

307

308

309

310

311

312

313

314

315

316

317

In the light of the results and analyses, the risk of P loss to waters based on the DPS is arguable.

The overall percentage of agricultural plots with soils at high risk for P loss by surface runoff (DPS $\geq 80$ ) was $96.7 \%$, correlating with $96 \%$ of plots that had mineral soils and $100 \%$ of plots that had organic soils. The obtained results indicate that soils were overly supplied with P and suggest that measures need to be taken in this area to prevent its outflow to waters, e.g. by decreasing phosphate fertilizer applications. However, the results of STPs revealed that in order to obtain satisfactory crops, the P content in assessed soils should be significantly increased rather than decreased (therefore, in terms of soil $\mathrm{P}$ management various or even contradictory conclusions emerge from environmental and agronomic assessments). Deficient soils were characterized by very low or low levels of P. In the case of plots with mineral soils, $72 \%$ were affected by this problem. In cases of serious $\mathrm{P}$ deficiencies in the soil, relatively small amounts 
318 of this component were found in the surface runoff (Pietrzak, Wesołowski \& Brysiewicz, 2017).

319 Given the episodic character of runoff, the risk of surface water quality problems under these

320 conditions should not be overestimated and STP and environmental soil P tests may have yielded

321 opposite assessments due to the P retention capacity in deficient soils. Such soils may be marked

322 by low $\mathrm{P}$ content as determined by an agronomic test method and a high risk of P release (Nair \&

323 Harris, 2004; Nair et al., 2010).

324 With regard to the STP, the vast majority of analyzed soils require increased applications of

325 phosphate fertilization and liming in order to optimize their $\mathrm{pH}$ for agricultural purposes. This

326 treatment would increase the solubility of the bound form of $\mathrm{P}$ in the soil and thus increase the

327 plant-available P. This treatment would be productively justified but could be considered

328 unnecessary in terms of WSP analysis.

329 Doubts over the adequacy of determining the risk of P loss from soil to water by means of DPS

330 threshold values were increased by the results of the assessment conducted with respect to all

331 analyzed organic soils, which were mainly under grasslands. DPS for these soils exceeded $80 \%$

332 each time so the risk of $\mathrm{P}$ loss to waters was high. However, it is difficult to take it as a deciding

333 conclusion as grassland is a biological filter that protects against the release of pollutants into

334 waters. This approach overlooks the contribution of landform features to the uncertain risk of $\mathrm{P}$

335 loss in surface runoff from agricultural soils to waters as determined by the DPS index. In these

336 assessments, the inclination factor should be taken into account as it contributes to the risk of 
337 surface runoff (Table 8); significant landfalls which undoubtedly affected the dynamics of $\mathrm{P}$

338 outflow to waters were identified in the research area. The outflow was shaped by a number of

339 other factors, including the physical and chemical soil properties ( $\mathrm{pH}$ and organic matter

340 content), soil and plant cultivation methods and atmospheric conditions (Ulen, 2013; Sapek,

341 2014). These factors should be considered comprehensively in the identifying of areas

342 susceptible to P losses. This approach is contained in a P index (Lemunyon \& Gilbert, 1993;

343 Sharpley et al., 2003), which is a measure of soil vulnerability to P movement from the field site

344 to waters. The P index is a widely used tool in the USA and Europe to assess the risk of P losses

345 from agricultural landscapes to surface waters (Buczko \& Kuchenbuch, 2007).

346 The problem of determining the risk of $\mathrm{P}$ loss in surface runoff from agricultural soils to waters

347 is complex. The assessment of such a risk should not depend solely on the value of the DPS

348 index. Therefore, the DPS indicator should be considered in conjunction with a set of parameters

349 characterizing the possibility of $\mathrm{P}$ losses from agriculturally used soils to watercourses and water

350 reservoirs.

351

352 Conclusion

353 The research was conducted on a typical undulating area of agricultural land in the Puck

354 Commune, $78.2 \%$ of which consisted of arable land and $21.8 \%$ of grassland. In terms of

355 mechanical composition, agricultural soils were predominantly medium and light textured, 
356 whereas alluvial soils were entirely of organic origin. The majority of the soils were

357 characterized by high acidity (more than $62 \%$ of agricultural plots had a very acidic or acid

358 reaction) and a deficiency of plant-available P. In the latter case, over $62 \%$ of the analyzed soils,

359 including $72 \%$ of mineral soils and over $18 \%$ of organic soils, were characterized by very low

360 and low P content. The DPS exceeded $80 \%$ in almost all of the assessed soils as determined on

361 the basis of $\mathrm{P}$ content extracted in the water extract. There was a high risk of $\mathrm{P}$ loss in surface

362 runoff to water after taking into the account the existing criteria of the DPS index assessment.

363 However, this assessment should be approached cautiously as it does not correspond to the

364 results of the agronomic assessment of the $\mathrm{P}$ content in soil in terms of the requirements for the

365 application of phosphate fertilization. It also disregards other factors affecting P loss in runoff,

366 such as the type of crop or area inclination.

367 The research results show that the risk assessments of $\mathrm{P}$ losses from agricultural soils performed

368 on the basis of soil P content testing with an environmental test method (e.g. using WSP content

369 and calculated DPS indicator) and an agronomic one (e.g. using P-AL content) can be

370 antagonistic. This indicates that there is still a problem in determining the risk of P loss in

371 surface runoff from agricultural land to water and further research is needed to develop a

372 solution.

\section{REFERENCES}


375 Ahtiainen H, Artell J, Elmgren R, Hasselström L, Håkansson C. 2014. Baltic Sea nutrient

376 reductions - What should we aim for? Journal of Environmental Management 145: 9-23.

377 DOI:10.1016/j.jenvman.2014.05.016

378 Alleoni LRF, Fernandes AR, de Campos M. 2014. Degree of phosphorus saturation of an Oxisol

379 amended with biosolids in a long-term field experiment. Environmental Science and Pollution

380 Research 21(8): 5511-5520. DOI:10.1007/s11356-013-2469-0.

381 Andersen JH, Axe P, Backer H, Carstensen J, Claussen U, Fleming-Lehtinen V, Järvinen M,

382 Kaartokallio H, Knuuttila S, Korpinen S, Kubiliute A, Laamanen M, Lysiak-Pastuszak E, Martin

383 G, Møhlenberg F, Murray C, Nausch G, Norkko A, Villnäs A. 2011. Getting the measure of

384 eutrophication in the Baltic Sea: Towards improved assessment principles and methods.

385 Biogeochemistry 106: 137-156. DOI:10.1007/s10533-010-9508-4.

386 Barszczewski J, Jankowska-Huflejt H, Mendra M. 2015. Renovation of permanent grassland.

387 Falenty: ITP Publishing House: 20. Available at

388 http://www.itp.edu.pl/wydawnictwo/mat informacyjne/Mat Inf\%2042.pdf (accessed 20

389 February 2019) (in Polish).

390 Brzeziński M, Barszczak T. 2009. The content of exchangeable aluminium in soil in view of

391 long-term fertilization experiments in Skierniewice. Advances of Agricultural Sciences Problem

392 Issues V. 541(1): 67-72 (in Polish). 
393 Buczko U, Kuchenbuch RO. 2007. Phosphorus indices as risk-assessment tools in the U.S.A. and

394 Europe - a review. Journal of Plant Nutrition and Soil Science 170(4): 445-460.

395 DOI:10.1002/jpln.200725134.

396 Casson JP, Bennett DR, Nolan SC, Olson BM, Ontkean GR, Little JL. 2006. Degree of

397 phosphorus saturation thresholds in Alberta soils. 40 pp. In: Alberta Soil Phosphorus Limits

398 Project. Volume 3: Soil sampling, manure application, and sorption characteristics. Alberta

399 Agriculture, Food and Rural Development, Lethbridge, Alberta, Canada: 48. Available at

400 http://citeseerx.ist.psu.edu/viewdoc/download?doi=10.1.1.536.6133\&rep=rep1\&type=pdf

401 (accessed 15 May 2019).

402 DEFRA. 2005. Environmental Stewardship. Producing a Soil Management Plan for

403 Environmental Stewardship: 22. Available at

404 http://adlib.everysite.co.uk/resources/000/107/821/soil-management-plan.pdf (accessed 15 May

405 2019).

406 Dzierzbicka-Głowacka L, Janecki M, Dybowski D, Szymczycha B, Obarska-Pempkowiak H,

407 Wojciechowska E, Zima P, Pietrzak S, Pazikowska-Sapota G, Jaworska-Szulc B, Nowicki A,

408 Kłostowska Ż, Szymkiewicz A, Galer-Tatarowicz K, Wichorowski M, Białoskórski M,

409 Puszkarczuk T. 2019. A new approach for investigating the impact of pesticides and nutrient flux

410 from agricultural holdings and land-use structures on the coastal waters of the Baltic Sea. Polish

411 Journal of Environmental Studies 28(4): 2531-2539. DOI:10.15244/pjoes/92524. 
412 Filipek T. 1989. Occurrence of exchangeable aluminium in the soil and its impact on plants.

413 Advances of Agricultural Sciences Problem Issues V 4/5/6: 3-14 (in Polish).

414 Fischer P. 2018. The degree of phosphorus saturation of agricultural soils in Brazil and

415 Germany: New approaches for risk assessment of diffuse phosphorus losses and soil phosphorus

416 management. PhD thesis: 129. DOI:10.18452/19589. Available at https://edoc.hu-

417 berlin.de/handle/18452/20359;jsessionid=720DF55810D021E4217F60AFC1E7518E (accessed

41815 May 2019).

419 Fisher P, Pöthig R, Gücker B, Venohr M. 2018. Phosphorus saturation and superficial fertilizer

420 application as key parameters to assess the risk of diffuse phosphorus losses from agricultural

421 soils in Brazil. Science of the Total Environment V. 630: 1515-1527.

422 DOI:10.1016/j.scitotenv.2018.02.070.

423 Fotyma M, Mercik S. 1995. Agricultural chemistry. Warsaw: Polish Scientific Publishers PWN

424 (in Polish).

425 Gaj R. 2008. Sustainable management of phosphorus in soil and plant. Fertilizers and

426 fertilization 33: 3-143 (in Polish).

427 Google Earth Pro 7.3.2.5776. 2019. Available at

428 https://www.google.com/intl/pl/earth/versions/\#earth-pro (accessed 15 May 2019). 
429 GUS. 2018. Statistical Yearbook of Agriculture 2018. Warsaw: Statistics Poland: 453. Available

430 at https://stat.gov.pl/obszary-tematyczne/roczniki-statystyczne/roczniki-statystyczne/rocznik-

431 statystyczny-rolnictwa-2018,6,12.html (accessed 24 June 2019).

432 GUS. 2019. Means of production in agriculture in the 2017/18 farming year. Warsaw: Statistics

433 Poland. Available at https://stat.gov.pl/obszary-tematyczne/rolnictwo-

434 lesnictwo/rolnictwo/srodki-produkcji-w-rolnictwie-w-roku-gospodarczym-20172018,6,15.html

435 (accessed 4 July 2019).

436 Hansen NE, Vietor DM, Munster CL, White RH, Provin TL. 2012. Runoff and nutrient losses

437 from constructed soils amended with compost. Applied and Environmental Soil Science 2012.

438 DOI:10.1155/2012/542873.

439 HELCOM. 2013. HELCOM Copenhagen Ministerial Declaration. Taking Further Action to

440 Implement the Baltic Sea Action Plan - Reaching Good Environmental Status for a healthy

441 Baltic Sea. Available at

442 http://www.helcom.fi/Documents/Ministerial2013/Ministerial\%20declaration/2013\%20Copenha

443 gen $\% 20$ Ministerial $\% 20$ Declaration $\% 20 \mathrm{w} \% 20$ cover.pdf (accessed 4 October 2019).

444 HELCOM. 2018a. Sources and pathways of nutrients to the Baltic Sea. Baltic Sea Environment

445 Proceedings No. 153. Available at http://www.helcom.fi/Lists/Publications/BSEP153.pdf

446 (accessed 15 May 2019). 
447 HELCOM. 2018b. State of the Baltic Sea - Second HELCOM holistic assessment 2011-2016.

448 Baltic Sea Environment Proceedings No. 155. Available at www.helcom.fi/baltic-sea-

449 trends/holistic-assessments/state-of-the-baltic-sea-2018/reports-and-materials/ (accessed 24 June 450 2019).

451 IUNG-PIB. Soil agricultural map of the Puck Commune to the scale of 1:25000. Puławy.

452 Jadczyszyn T, Kowalczyk J, Lipiński W. 2010. Nutrient recommendations for field crops and

453 grassland. Training Materials. Puławy: IUNG-PIB Publishing House No. 95: 24 (in Polish).

454 Kocoń A. 2014. Effectiveness of liming and fertilization on light acid soils and yield of plants

455 and selected indicators of soil fertility. Fragmenta Agronomica 31(3): 66-74 (in Polish).

456 Lemunyon J, Gilbert RG. 1993. The concept and need for a phosphorus assessment tool. Journal

457 of Production Agriculture 6(4): 483-486. DOI:10.2134/jpa1993.0483.

458 Nair VD, Harris WG. 2004. A capacity factor as an alternative to soil test phosphorus in

459 phosphorus risk assessment. New Zealand Journal of Agricultural Research 47: 491-497.

460 DOI:10.1080/00288233.2004.9513616.

461 Nair VD, Harris WG, Chakraborty D, Chrysostome M. 2010. Understanding soil phosphorus

462 storage capacity. SL 336. Gainesville: University of Florida, Institute of Food and Agricultural

463 Sciences. Available at http://edis.ifas.ufl.edu/pdffiles/SS/SS54100.pdf (accessed 22 July 2019). 
464 Nair VD, Portier KM, Graetz DA, Walker ML. 2004. An environmental threshold for degree of

465 phosphorus saturation in sandy soils. Journal of Environmental Quality 33(1): 107-113.

466 DOI:10.2134/jeq2004.0107.

467 National Water Management Board. 2016a. National program for the protection of marine

468 waters - Report to the European Commission: 170. Available at

469 https://www.kzgw.gov.pl/files/kpowm/kpowm-2016.pdf (accessed 15 May 2019) (in Polish).

470 National Water Management Board. 2016b. Report on the implementation of the provisions of

471 the Council Directive 91/676/EEC of 12 December 1991 concerning the protection of waters

472 against pollution caused by nitrates from agricultural sources in the period: 01.05.2012-

473 30.04.2016-Draft Report. Available at

474 http://www.krir.pl/images/179 2016_raport_OSN_Podzadanie_II_1_v_1_1.pdf (accessed 15

475 May 2019) (in Polish).

476 Ojaveer H, Jaanus A, MacKenzie BR, Martin G, Olenin S, Radziejewska T, Telesh I, Zettler

477 ML, Zaiko A. 2010. Status of biodiversity in the Baltic Sea. Plos One 5.

478 DOI:10.1371/journal.pone.0012467.

479 Pietrzak S, Majewska Z, Wesołowski P. 2016. The suitability of degree of phosphorus saturation

480 indicator to assess the risk of losses this compound by runoff to surface water - case study.

481 Water-Environment-Rural Area V. 16/2(54): 89-98 (in Polish). 
482 Pietrzak S, Wesołowski P, Brysiewicz A. 2017. Correlation between the quantity of phosphorus

483 in the soil and its quantity in the run-off from a cultivable field on a selected farm. Journal of

484 Elementology 22(1): 105-114. DOI:10.5601/jelem.2016.21.1.1103.

485 PN-EN 12879:2004. Characterization of sludges - Determination of the loss on ignition of dry

486 mass. Polish Committee for Standardization (in Polish).

487 PN-EN ISO 17892-4:2016. International Standard. Geotechnical investigation and testing -

488 Laboratory testing of soil - Part 4: Determination of particle size distribution. Polish Committee

489 for Standardization (in Polish).

490 PN-ISO 10390:1997. Polish Standard: Quality of soil. Determination of pH. Polish Committee

491 for Standardization (in Polish).

492 PN-R-04023:1996. Polish Standard: The chemical and agricultural analysis of the soil.

493 Determination of the content of assimilable phosphorus in mineral soils. Polish Committee for

494 Standardization (in Polish).

495 PN-R-04024:1997. Polish Standard: The chemical and agricultural analysis of the soil.

496 Determination of the content of assimilable phosphorus, potassium, magnesium and manganese

497 in organic soils. Polish Committee for Standardization (in Polish).

498 PN-R-04031:1997. Polish Standard: The chemical and agricultural analysis of the soil. Sampling.

499 Polish Committee for Standardization (in Polish). 
500 Pole DH, Daniel TC, Sharpley AN, Moore PA, Edwards DR, Nichols DJ. 1996. Relating

501 extractable soil phosphorus to phosphorus losses in runoff. Soil Science Society of American

502 Journal 60(3): 855-859. DOI:10.2136/sssaj1996.03615995006000030025x.

503 Pöthig R, Behrendt H, Opitz D, Furrer G. 2010. A universal method to assess the potential of

504 phosphorus loss from soil to aquatic ecosystems. Environmental Science and Pollution Research

505 17(2): 497-504. DOI:10.1007/s11356-009-0230-5.

506 Puck Commune Office. 2016. Environmental Protection Scheme for the Puck Commune for the

507 period 2013-2016 with 2017-2020 Scenario. Available at

508 http://bip.gmina.puck.pl/dokumenty/172 (accessed 24 June 2019) (in Polish).

509 Sapek A. 2007. Reasons for the increase of phosphorus resources in Polish soils. Soil Science

510 Annual 58(3/4): 110-118 (in Polish).

511 Sapek B. 2014. Soil phosphorus accumulation and release - sources, processes, causes. Water-

512 Environment-Rural Area 14(1): 77-100 (in Polish).

513 Schierer RA, Davis JG, Zumbrunnen JR. 2006. Predicting phosphorus runoff from calcareous

514 soils. Better Crops with Plant Food 90(4): 3-5. Available at

515 http://www.ipni.net/publication/bettercrops.nsf/0/26C5DE89F4BC648E8525798000770E8C/\$FI

516 LE/Better\%20Crops\%202006-4\%20(10\%20res).pdf (accessed 4 July 2019).

517 Schindler FV, German D, Gelderman R. 2002. Establishing a relationship between soil test P

518 and runoff P for a South Dakota soil using simulated rainfall. Annual Report. Available at 
519 https://water.usgs.gov/wrri/AnnualReports/2002/FY2002 SD Annual Report.pdf (accessed 15

520 May 2019).

521 Sharpley AN, Smith SJ, Berg WA, Williams JR. 1985. Nutrient runoff losses as predicted by

522 annual and monthly soil sampling. Journal of Environmental Quality 14(3): 354-360.

523 DOI:10.2134/jeq1985.00472425001400030010x.

524 Sharpley AN, Kleinman P. 2003. Effect of rainfall simulator and plot scale on overland flow and

525 phosphorus transport. Journal of Environmental Quality 32(6): 2172-2179.

526 DOI:10.2134/jeq2003.2172.

527 Sharpley AN, Weld JL, Beegle DB, Kleinman PJA, Gburek WJ, Moore PA, Mullins G. 2003.

528 Development of phosphorus indices for nutrient management planning strategies in the United

529 States. Journal of Soil and Water Conservation 58(3): 137-151.

530 Siebielec G, Smreczak B, Klimkowicz-Pawlas A, Kowalik M, Kaczyński R, Koza P, Ukalska-

531 Jaruga A, Łysiak M, Wójtowicz U, Poręba L, Chabros E. 2017. Report on the third phase of the

532 contract „, Monitoring of arable soils chemism in Poland in 2015-2017“. Puławy: IUNG-PIB

533 Publishing House: 190. Available at

534 http://www.gios.gov.pl/images/dokumenty/pms/monitoring_jakosci_gleb/Raport_MChG_etap3.

535 pdf (accessed 4 July 2019) (in Polish).

536 StatSoft. Statistica Features. Available at http://www.statsoft.com/Products/STATISTICA-

537 Features (accessed 9 October 2019). 
538 Szymanowski M. 1995. Mineral and organic soils and their production value. Scientific Session,

539 Falenty 6-7.XI.1995. Seminar Materials. Falenty: IMUZ Publishing House 34: 351-355 (in

540 Polish).

541 Torbert HA, Daniel TC, Lemunyon JL, Jones RM. 2002. Relationship of soil test phosphorus

542 and sampling depth to runoff phosphorus in calcareous and noncalcareous soils. Journal of

543 Environmental Quality 31(4): 1380-1387. DOI:10.2134/jeq2002.1380.

544 Ulén B. 2013. Estimating the risk of phosphorus leaching from individual fields based on soil

545 surveys and fertilisation. In: Ulén B, Pietrzak S, Tonderski K, eds. Self-evaluation offarms for

546 improved nutrient management and minimised environmental impact. Falenty: ITP Publishing

547 House: 42-46. Available at http://balticsea2020.org/english/images/Bilagor/2014\%20Guide\%20-

548 \%20Self-evaluation\%20of\%20farms.pdf (accessed 15 May 2019) (in Polish).

549 Venohr M, Hirt U, Hofmann J, Opitz D, Gericke A, Wetzig A, Natho S, Neumann F, Hürdler J,

550 Matranga M, Mahnkopf J, Gadegast M, Behrendt H. 2011. Modelling of Nutrient Emissions in

551 River Systems - MONERIS - Methods and Background. International Review of Hydrobiology

552 96: 435-483. DOI:10.1002/iroh.20111133.

553 Von Tucher S, Hörndl D, Schmidhalter U. 2018. Interaction of soil pH and phosphorus efficacy:

554 Long-term effects of P fertilizer and lime applications on wheat, barley and sugar beet. Ambio 47

555 (Suppl 1): 41-49. DOI:10.1007/s13280-017-0970-2. 
Figure 1

Correlation between DPS and WSP indicators of soils; own elaboration (Pöthig et al., 2010).

Explanation: $r^{2}$ - value refers to the data of Pöthig et al., 2010.

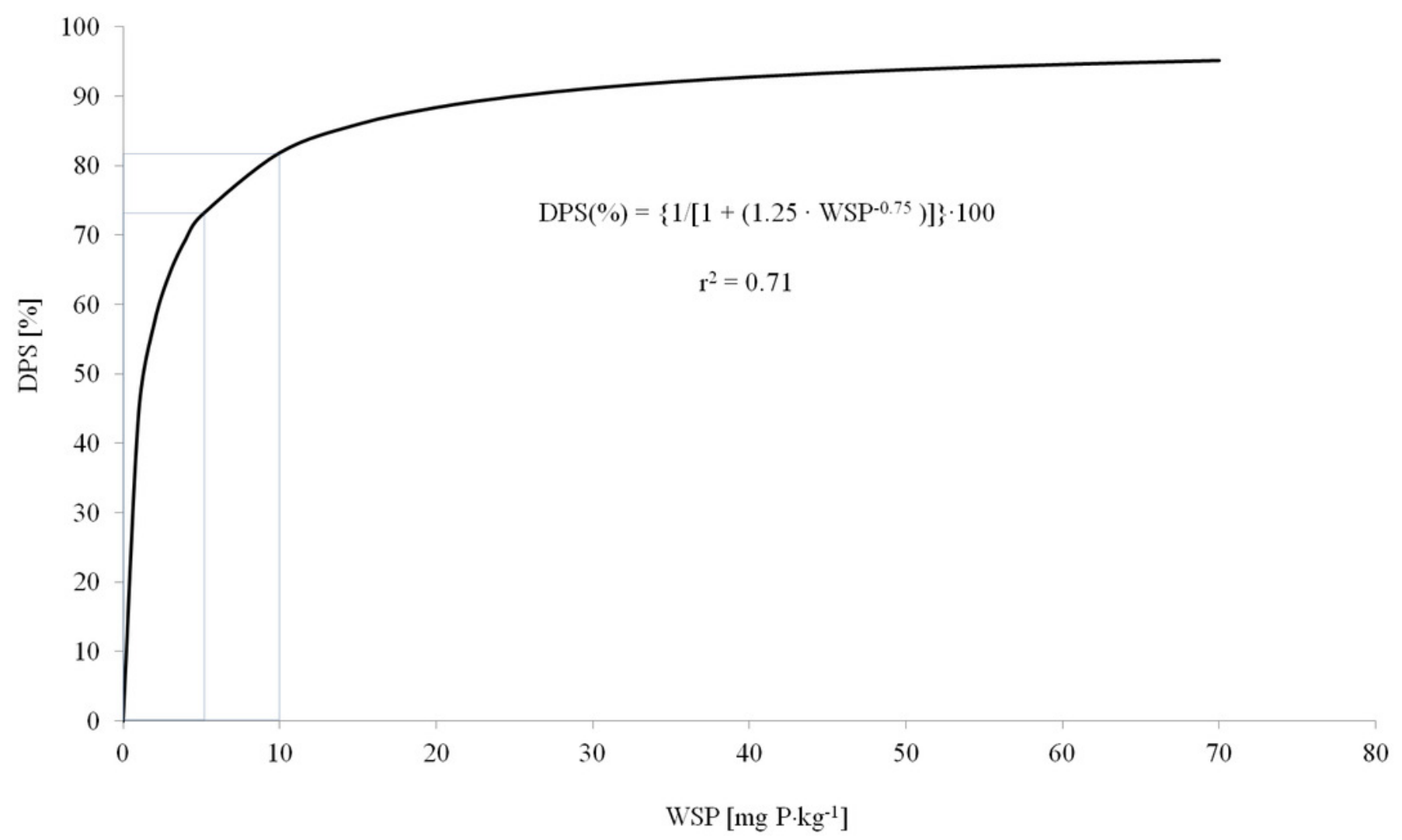




\section{Figure 2}

View of an exemplary agricultural plot from the research area and the shape of its longitudinal profile (Google Earth Pro 7.3.2.5776.2019. Agricultural plot in Sławutowo (Poland) $54^{\circ} 40^{\prime} 12.58^{\prime \prime} \mathrm{N}, 18^{\circ} 21^{\prime} 1.79^{\prime \prime} \mathrm{E}$, elevation 40M. 3D map. Viewed 22 February 2019)

Map Credit: Google Earth, Digital Globe (C) 2018

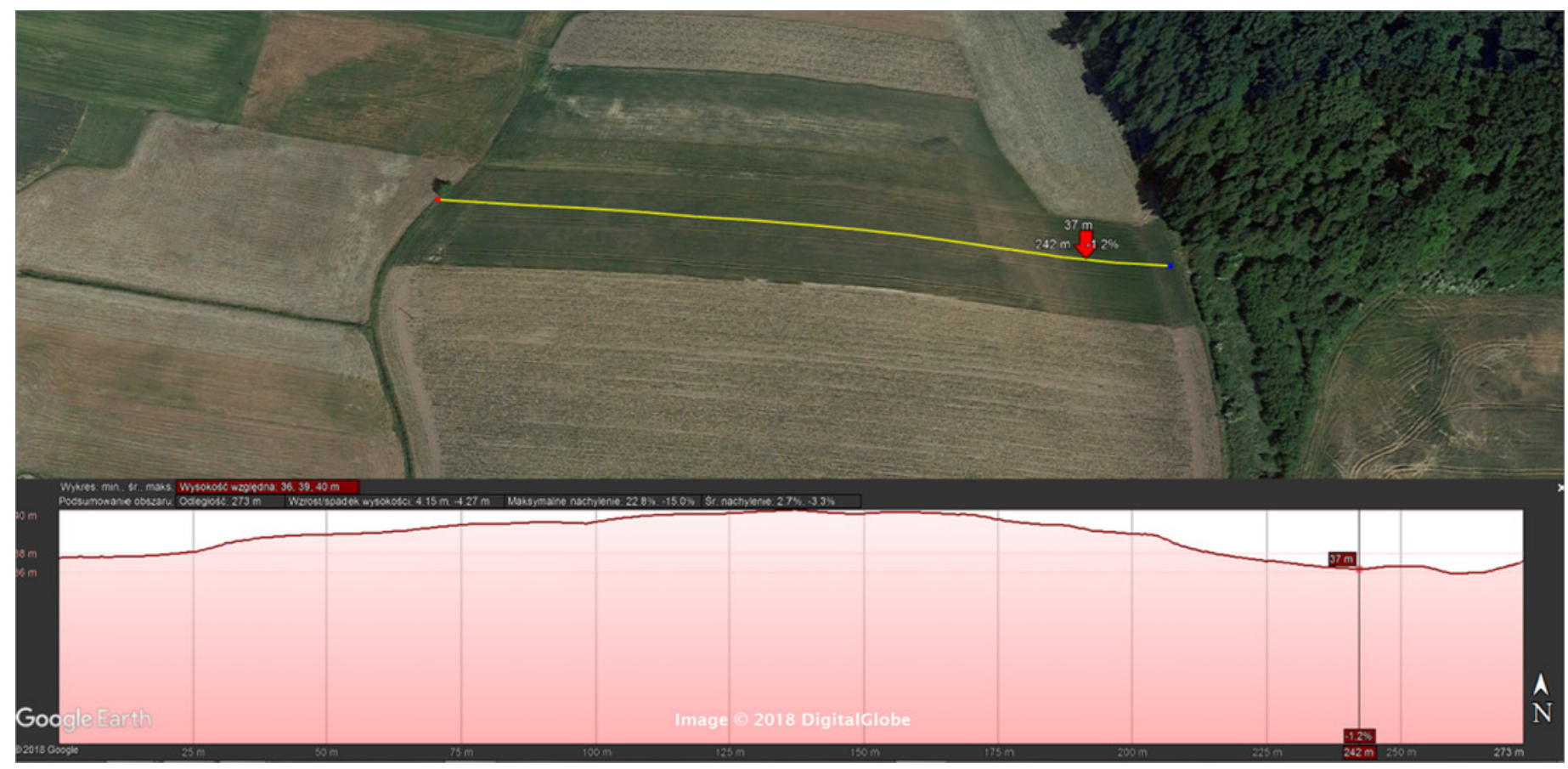


Figure 3

Distribution of soil $\mathrm{pH}$ in tested agricultural plots in the $0-30 \mathrm{~cm}$ layer.

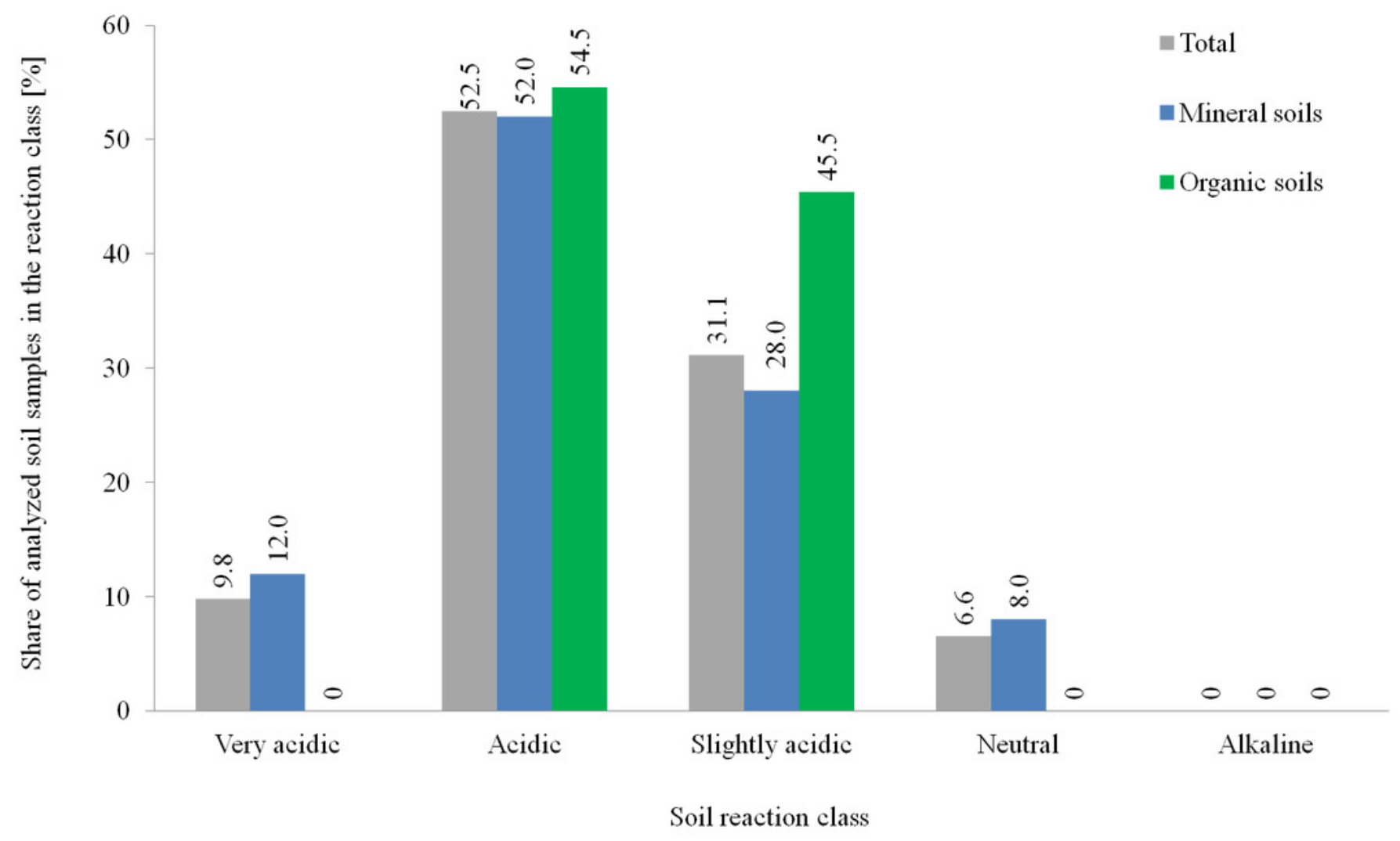


Figure 4

Distribution of soil P content in tested agricultural plots in the $0-30 \mathrm{~cm}$ layer.

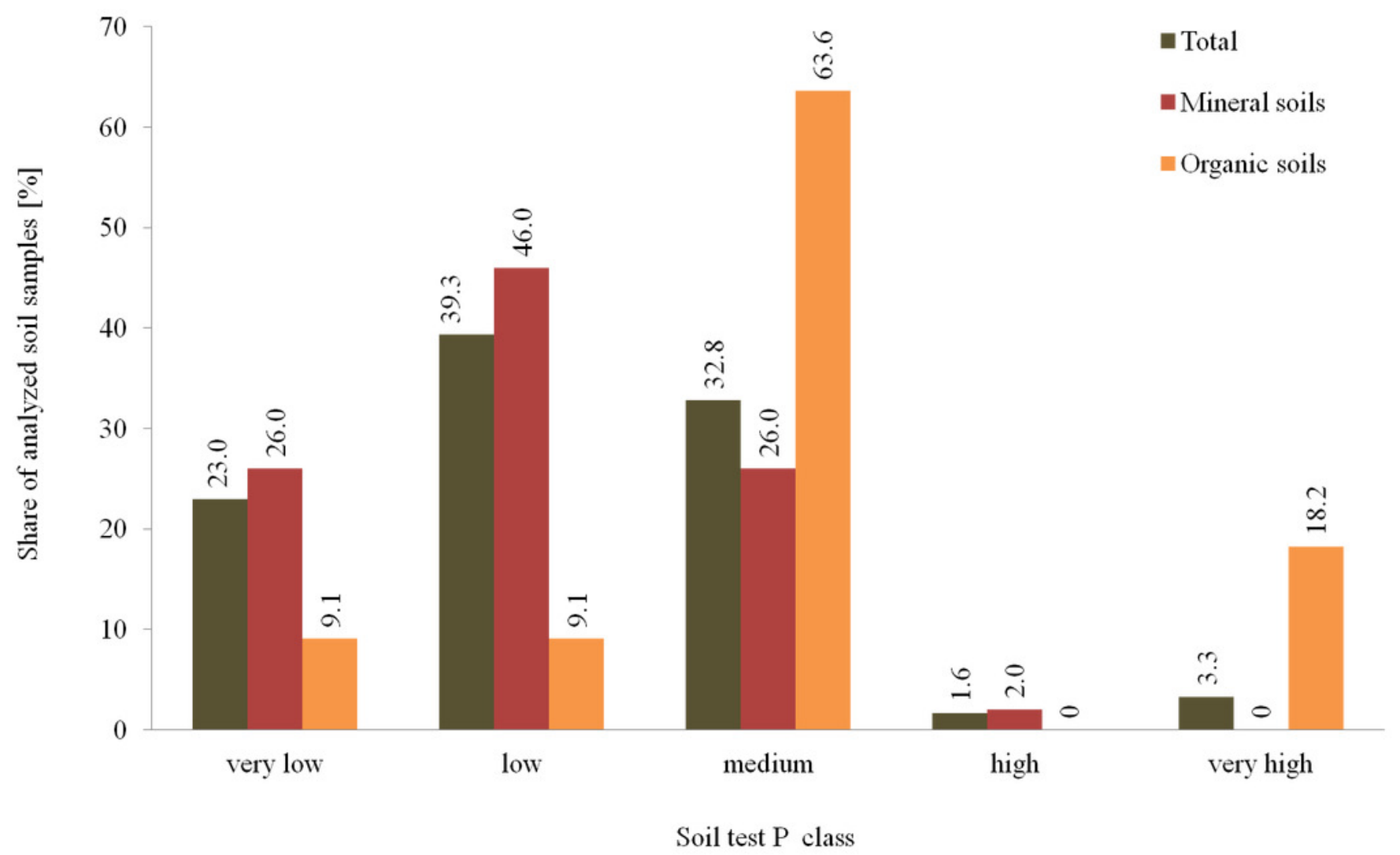


Figure 5

Spatial arrangement of studied agricultural plots in the Puck Commune with marked soil $\mathrm{pH}$ and $\mathrm{P}$ content in the $0-30 \mathrm{~cm}$ layer; own elaboration. 


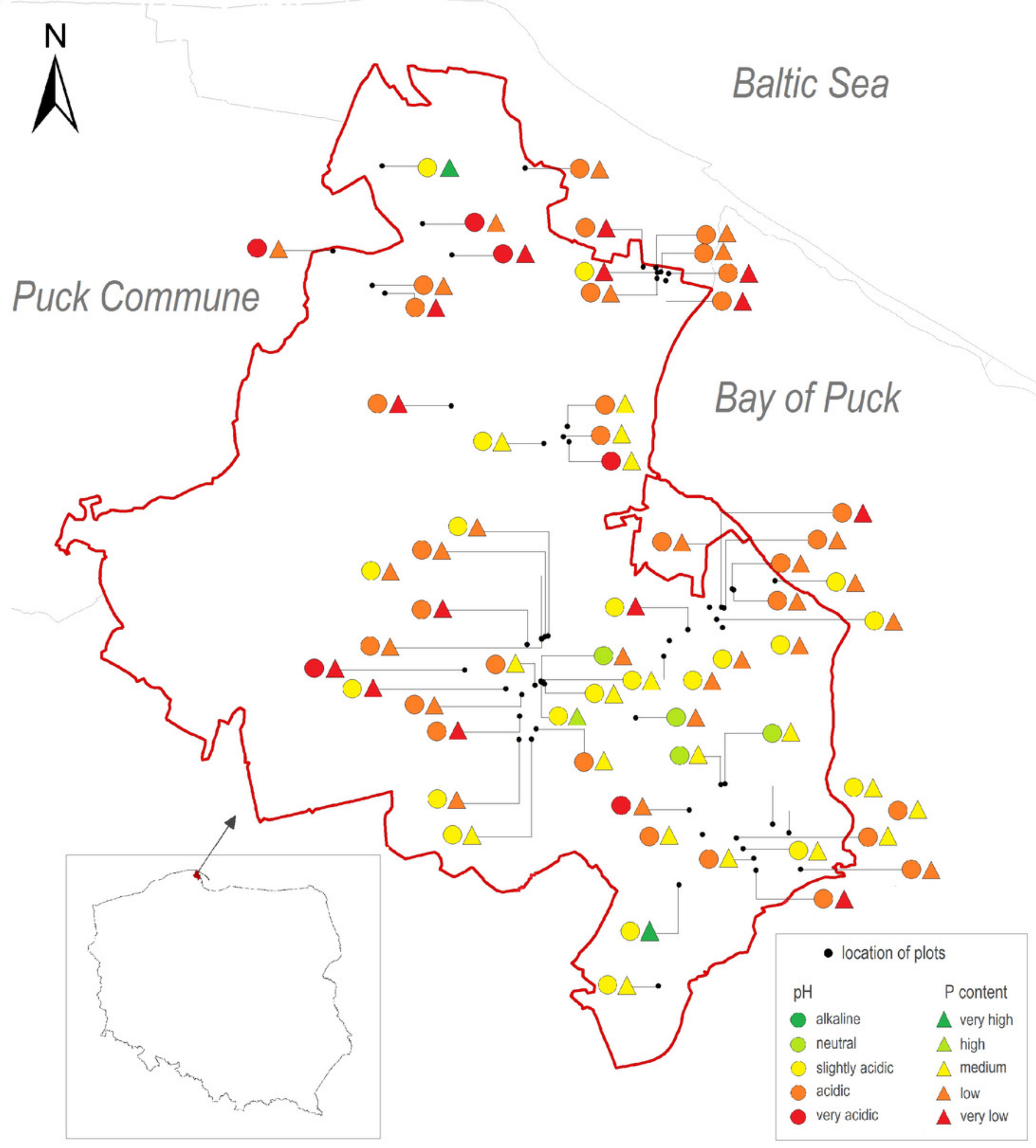




\section{Table $\mathbf{1}$ (on next page)}

Soil test $\mathrm{P}$ concentrations according to the Polish agronomic interpretation; own elaboration (PN-PN-R-04023; PN-R-04024:1997). 
1

\begin{tabular}{|c|c|c|}
\hline \multirow{2}{*}{$\begin{array}{c}\text { Concentration } \\
\text { class }\end{array}$} & \multicolumn{2}{|c|}{ Content, mg P· $\mathbf{k g}^{-1}$ of soil dry matter } \\
\hline & mineral soils & organic soils \\
\hline very low & $\leq 22$ & $\leq 174$ \\
\hline low & $(22-44]$ & $(174-262]$ \\
\hline medium & $(44-65]$ & $(262-349]$ \\
\hline high & $(65-87]$ & $(349-523]$ \\
\hline very high & $>87$ & $>523$ \\
\hline
\end{tabular}

2 
Table 2 (on next page)

Distribution of mineral $\mathrm{P}$ fertilizers consumption in a group of 22 farms. 


\begin{tabular}{|c|c|c|c|c|c|c|}
\hline \multirow{2}{*}{ Specification } & \multicolumn{6}{|c|}{ P fertilizers doses, $\mathrm{kg} \mathrm{P} \cdot \mathrm{ha}^{-1} \mathrm{AL}$} \\
\hline & $\mathbf{0}$ & $(0-5]$ & $(5-10]$ & $(10-15]$ & $(15-20]$ & $>\mathbf{2 0}$ \\
\hline Share of farms, $\%$ & 13.6 & 9.1 & 22.7 & 31.8 & 4.5 & 18.2 \\
\hline
\end{tabular}

1 


\section{Table 3(on next page)}

Statistical characteristic of the DPS indicator for studied plots.

Explanation: $\mathrm{n}$ - number of samples, $\mathrm{X}$ - mean, $\mathrm{SD}$ - standard deviation, Max - maximum value, Min - minimum value. 


\begin{tabular}{|c|c|c|c|}
\hline \multirow{2}{*}{ Parameter } & \multicolumn{3}{|c|}{ DPS value, \% } \\
\cline { 2 - 4 } & mineral soils $(\mathbf{n}=\mathbf{5 0})$ & organic soils $(\mathbf{n}=\mathbf{1 1})$ & total soils $(\mathbf{n}=\mathbf{6 1})$ \\
\hline $\mathrm{X}$ & 87.8 & 91.4 & 88.4 \\
\hline $\mathrm{SD}$ & 5.7 & 3.4 & 5.5 \\
\hline Max & 94.4 & 95.5 & 95.5 \\
\hline Min & 59.1 & 85.1 & 59.1 \\
\hline
\end{tabular}

1 


\section{Table 4(on next page)}

Share of agricultural plots with soils in various DPS classes. 


\begin{tabular}{|c|c|c|c|c|}
\hline \multirow{2}{*}{$\begin{array}{c}\text { DPS classes, } \\
\%\end{array}$} & \multirow{2}{*}{$\begin{array}{c}\text { Risk of } \mathbf{P} \\
\text { loss from soil: }\end{array}$} & \multicolumn{3}{|c|}{ Type of soil } \\
\cline { 3 - 5 } & & mineral & organic & total \\
\cline { 3 - 5 } & lack & $1(2.0)$ & $0(0.0)$ & $1(1.6)$ \\
\hline $70<$ & acceptable & $1(2.0)$ & $0(0.0)$ & $1(1.6)$ \\
\hline$[70-80)$ & big & $48(96.0)$ & $11(100.0)$ & $59(96.7)$ \\
\hline$\geq 80$ & & &
\end{tabular}

1 


\section{Table 5 (on next page)}

Sorption properties of brown soil made of sandy loam which originates from agriculture land located near the research area $\left(54^{\circ} 45^{\prime} 22^{\prime \prime} \mathrm{N}, 18^{\circ} 16^{\prime} 44^{\prime \prime} \mathrm{E}\right)$ according to data from 2015 (Siebielec et al., 2017). 


\begin{tabular}{|l|c|}
\hline Parameter defining soil sorption properties & Value \\
\hline Hydrolytic acidity $(\mathrm{HAC}), \mathrm{cmol}(+) \cdot \mathrm{kg}^{-1}$ & 4,65 \\
\hline Exchangeable acidity (EA), $\mathrm{cmol}(+) \cdot \mathrm{kg}^{-1}$ & 0,46 \\
\hline Exchangeable aluminium (ExAl), $\mathrm{cmol}(+) \cdot \mathrm{kg}^{-1}$ & 0,27 \\
\hline Total exchangeable bases (TEB), $\mathrm{cmol}(+) \cdot \mathrm{kg}^{-1}$ & 3,99 \\
\hline Cation exchange capacity (CEC), $\mathrm{cmol}(+) \cdot \mathrm{kg}^{-1}$ & 8,64 \\
\hline Base saturation of soil (BS), \% & 46,16 \\
\hline
\end{tabular}

1 


\section{Table 6 (on next page)}

Correlations between analysed indices of mineral soils.

Explanation: $\mathrm{pH}_{\mathrm{KCl}}-$ soil acidity measured in a suspension of $\mathrm{KCl}$ solution; $\mathrm{P}_{\mathrm{AL}}-\mathrm{P}$ content in soil determined in acid ammonium lactate; WSP - water soluble P content; DPS - degree of P saturation; w1 - soil layer $0-5 \mathrm{~cm}$; w2 - soil layer $0-30 \mathrm{~cm}$; ${ }^{*}$ correlation significant at $\alpha=$ 0.05 ; ** - correlation significant at $\alpha=0.01$. 


\begin{tabular}{|c|c|c|c|c|c|}
\hline \multirow{2}{*}{ Index } & $\mathbf{p H}_{\mathrm{KCl}}$ & $\mathbf{P}_{\mathrm{AL} \_} \mathbf{w 1}$ & $\mathbf{P}_{\mathrm{AL} \_} \mathbf{w} 2$ & WSP_w1 & DPS \\
\hline & \multicolumn{5}{|c|}{ Spearman rank correlation coefficient $(R)$} \\
\hline $\mathbf{p H}_{\mathrm{KCl}}$ & & $0.3244 *$ & $0.3655^{* *}$ & $0.4017 * *$ & $0.4017 * *$ \\
\hline $\mathbf{P}_{\mathrm{AL} \_} \mathbf{w 1}$ & & & $0.9552 * *$ & $0.8474 * *$ & $0.7474 * *$ \\
\hline $\mathbf{P}_{\mathrm{AL} \_} \mathbf{W} 2$ & & & & $0.8176 * *$ & $0.8176^{* *}$ \\
\hline WSP_w1 & & & & & $1 * *$ \\
\hline
\end{tabular}

1 


\section{Table 7 (on next page)}

Correlation between analysed indices of organic soils.

Explanation: $\mathrm{P}_{\mathrm{HCl}}-\mathrm{P}$ content in soil determined in the extract of $0.5 \mathrm{~mol} \mathrm{HCl} \cdot \mathrm{dm}^{-3}$; for additional explanations refer to Table 6 . 


\begin{tabular}{|c|c|c|c|c|c|}
\hline \multirow{2}{*}{ Index } & $\mathbf{p H}_{\mathrm{KCl}}$ & $\mathbf{P}_{\text {HCl_w1 }}$ & $\mathbf{P}_{\mathrm{HCl} \_w 2}$ & WSP_w1 & DPS \\
\hline & \multicolumn{5}{|c|}{ Spearman rank correlation coefficient $(R)$} \\
\hline $\mathrm{pH}_{\mathrm{KCl}}$ & & 0.4771 & 0.4828 & 0.4863 & 0.4863 \\
\hline$P_{\mathrm{HCl} \_w 1}$ & & & $0.6196^{*}$ & 0.0866 & 0.0866 \\
\hline $\mathbf{P}_{\text {HCL_w2 }}$ & & & & 0.3091 & 0.3091 \\
\hline WSP_w1 & & & & & $1 * *$ \\
\hline
\end{tabular}

1 


\section{Table 8 (on next page)}

Assessment of runoff risk for all soil types; own elaboration (DEFRA 2005). 


\begin{tabular}{|c|c|c|c|c|}
\hline \multirow{2}{*}{ Specification } & \multicolumn{4}{|c|}{ Inclination: } \\
\cline { 2 - 5 } & $>7^{\circ}$ & $\mathbf{3 - 7 ^ { \circ }}$ & $\mathbf{2 - 3}^{\circ}$ & $<\mathbf{2}^{\circ}$ \\
& $(\mathbf{1 2 . 3 \% )}$ & $\mathbf{( 5 . 2 - 1 2 . 3 \% )}$ & $\mathbf{( 3 . 5 - 5 . 2 \% )}$ & $\mathbf{( 3 . 5 \% )}$ \\
\hline runoff risk & high & moderate & lower & lower \\
\hline
\end{tabular}

1 